\title{
THE ROLE OF INVESTOR PROTECTION MODERATION IN THE EFFECT OF CORPORATE GOVERNANCE ON EARNINGS QUALITY
}

\author{
Syaifullah As'ad \\ Department of Accounting, Faculty of Economics and Business, University of Airlangga, \\ Surabaya, Indonesia \\ E-mail: asadsaifullah1@gmail.com
}

\begin{abstract}
This study aims to examine the role of investor protection moderation on the effect of corporate governance on the quality of earnings. The population of this study was 50 nonfinancial companies listed on the ASEAN country Stock Exchange covering the countries of Indonesia, Malaysia, Philippines, Singapore, and Thailand during 2011-2015. This study uses a purposive sampling method, with a total sample of 250 companies. The data analysis technique used is moderated regression analysis. The results of this study state that investor protection strengthens the influence of corporate governance on the quality of earnings that is proxied by earnings management. Based on the results of testing, it was found that moderation in protection of investors with corporate governance can improve supervision and monitoring of financial reporting policies carried out by management so that the better the legal system in a country and the better implementation of corporate governance in the company, the minority investors easier to control to the management of financial reporting policies and decision-making related to accounting policies so that it can put pressure on management and management to be careful in reporting company finances which in turn affect the quality of earnings.
\end{abstract}

\section{KEY WORDS}

Investor protection, corporate governance, earnings, quality.

The purpose of investors in investing is to obtain continuous profits in the future, where profits motivate investors to invest in a certain investment. (Jakfar, 2012). Based on the investment period, long-term investment in the capital market can be done with two choices, namely bond or stock investment (Basalamah \& Jermias, 2005).

In evaluating management's performance, predicting the flow and magnitude of cash in the future, and estimating the amount of earnings power, investors and creditors require profit information generated by financial statements, where profit is a measure of management performance in a company. Therefore company performance can actually be shown from the value of earnings quality so that it is not meaningful accounting value in the financial statements. So it is very important the quality of earnings from the company's annual report. Many investors are wrong in making investment decisions in allocating capital and misleading other users of financial statements due to the low value of earnings quality (Rinawati, 2011).

The quality of earnings information can come and be influenced by external and internal factors. Internal factors are related to the application of corporate governance while external factors are related to investor protection. The investor protection is related to the legal institutional environment that applies to a country. Following are some international studies that examine the relationship between investor protection and earnings quality from investor and manager interference in controlling the laws and politics of a country, based on research by La Porta et al. (2002) where in his research added capital market law (securities law) as a mechanism for implementing protection for investors. Protection mechanisms for investors are used as fundamental factors of capital market law, namely litigation standards, disclosure requirements, and public enforcement. Litigation standards are related to the level of difficulty in compensating for the errors in the presentation of annual financial reports and in the prospectus. While this public enforcement reflects the strength of institutions in the 
capital market in implementing regulations such as central bank institutions. The characteristic size of the capital market supervisory institution includes the power to impose sanctions in the form of stopping the trading of company shares, the strength of conducting investigations, the power in making regulations, and giving criminal penalties when the information presented is not material. While disclosure requirements are fundamental factors regarding equipment requirements to present the company's prospectus.

While the study by Leuz et al. (2003) found a relationship between the protections of investors to the quality of earnings, in which the research linked earnings quality with dimensions earnings management as a measure to determine the quality of earnings. The basic understanding of this research is that insiders, namely the stockholders main and managers, have incentives in expropriating and taking private control benefits to minority shareholders through earnings management. However, the existence of a legal system that protects the rights of minority investors is able to limit the ability of these insiders. Minority investors can take legal steps when there is suspicion of opportunistic actions that are done by insiders. Therefore earning management will be smaller in companies in countries that apply high investor protection. The conclusion in this study is to state that there is a negative correlation between public enforcement and the rights of minority shareholders and earnings management and underlines the importance of the relationship between the quality of accounting earnings and protection for investors.

Wardhani (2009) in his research found that investor protection has a positive effect on earnings predictability coefficient. The financial statements disclosed will be even more informative when the stronger investor protection prevails in a country. Strong investor protection by a country shows that the quality of law enforcement and regulations that are owned by the state is strong so that company management will be required to apply high standards to avoid sanctions from the government, causing management to improve the quality of information from the company's financial statements.

From the explanation of some of the statements above shows that disciplining the law and legal system in the form of applicable accounting standards in a country provides increased pressure on company management in producing more qualified financial reports and is useful to provide increased protection for investors. While corporate governance is an internal factor that can motivate company management in preparing financial statements related to commitment in disclosing quality and quality financial statements.

In a company the application of corporate governance has an impact on the quality of earnings. Where in previous studies as in Xie et al. (2003); Marsia and Alan (2009); Jerry and Mark (2009) states that companies that implement good corporate governance will have an impact on the quality of reported earnings. In his research also found a positive correlation between the quality of earnings measured using earnings management with the steps of implementing corporate governance. In general, the conclusions in this study found a positive effect of the application of corporate governance on the quality of earnings.

Other research findings related to the application of corporate governance to earnings quality, Niu (2006) and Petra (2007), Dechow (1994), Klein (2002), Xie et al. (2003), Ahmed and Duellman (2007), and Ball et al. (2000) who concluded that the quality of earnings will increase when the implementation of corporate governance in the company is very good. The meeting shows that in addition to protection for investors, the application of corporate governance to companies also provides incentives to management in preparing financial reporting, which affects the quality of profits disclosed. Therefore the company will be more transparent and better in preparing its financial report when the company implements good corporate governance, so that the profit value presented will have higher quality.

Corporate governance according to Annisa and Kurniasih (2012) is a system that connects the interests of company management with stockholders to explain the direction of company performance. Implementation of corporate governance can minimize agency conflict as a result of differences in interests. Differences in interests that result in agency conflict are caused by not being able to keep up with what the shareholders want to achieve with the importance of company managers. Stockholders want the resulting profits to be distributed as dividends from invested capital. While managers want the profits generated for 
retained earnings that can be used in the company's operational activities in the future. These differences in interests can affect financial reporting policies that are used to present company performance. The implementation of corporate governance greatly determines the company's financial reporting policies. The profits generated by the company will be used as a basis for financial reporting. Where a large profit will have an impact on the commission that will be received by management. So that the implementation of corporate governance will also reduce earnings management actions carried out by managers when the company has a large debt.

From some of the results of previous studies regarding investor protection of earnings quality and the effect of implementation corporate governance on earnings quality, it can be concluded that investor protection and implementation corporate governance have a significant influence but are still in the regression test phase which is still not connected with other variables where previous studies have not never conducted research in ASEAN countries, so this motivated the authors to do different tests by making investor protection as a moderating variable from the study. So that the authors more deeply examine the relationship between the applications of corporate governance towards profit quality that is moderated by investor protection for companies in ASEAN countries for the period 20112015. The reason researchers chose ASEAN countries is because the country is still in one region so that different cultural factors are minimized and these countries have also adopted IFRS since 2011. This research period in 2011-2015 was due to ASEAN countries adopting IFRS in 2011 so that they did not there is another influence on the accounting policy recording system of each company in ASEAN countries. So that the published financial statements are in harmony there is no difference.

\section{LITERATURE REVIEW}

Agency Theory. G. Maharani and K. Suardana (2014) explain that there is an agreement between the agent and the principal to give authority to the agent to manage the principal source of capital to make policy in making decisions. In a long time the manager tends to take action in accordance with his interests and no longer follows the interests expected by the principal. Although the principal understands the differences in interests with the manager, the principal understands the limits so that the differences still have the same vision.

Agency theory informs the differences between agents and principals regarding conflicts of interest. In explaining the differences in conflicts of interest raises several costs, namely agency costs, monitoring costs, and costs bonding. Agency costs are costs that arise as a result of trying to equalize these interests. In equalizing these interests raises monitoring costs where the costs will be issued by the principal in providing compensation to the agent, the principal hopes that the compensation will minimize differences in interests that could lead to future losses. Whereas bonding costs are compensation costs by the agent as a result of the agent's actions that harm the principal. Bonding costs are often said to be a guarantee that the agent acts in accordance with the interests of the principal.

In addition to the decline in the number of principal resources resulting from the three agency costs, namely causing differences in decision making between agents and principals where agents as decision makers in companies and principals are the owners of capital. This reflects that the cooperation contract between agents and principals is equally very strong. Where this means that in order to be able to supervise all agency actions, the principal must give up some of his resources so that the agent can move according to the expectations of the principal's interests. While the agent must provide a guarantee to give trust to the principal in taking responsibility for the authority given by the principal.

Jensen and Meckling in (G. Maharani \& K. Suardana, 2014) state that besides occurring at the management level in organizational structures from low level and from high level, agency conflicts occur in modern companies, so that the existence of conflict agencies is expected to minimize differences in interests at the level of company management. This agency conflict arises in the era of modern companies because there are opinions related to 
supervision and ownership which are separated so that it is common in the corporate environment.

Earning Quality. Quality of earnings is the level at which earnings information is able to describe the actual economic influence of a transaction. So that it has a reflection in the presentation of earnings information in financial statements. The success of the company in a certain period can be seen from the results of the calculation of the loss report that provides information to creditors and investors in predicting the time, amount and certainty of future cash flows that can be obtained by the company (Warfield, 2010). Therefore, for the management of individual manager performance can be measured through the income statement. So that the income statement becomes a very important tool for assessing the performance of managers both the flexibility of managers in determining the policy of accounting methods to improve profit quality in the company's income statement which is certainly different between one company and another company. Therefore the conclusion that can be drawn is that earnings information is said to have quality when earnings information has forecasting abilities, honest and timely presentation, neutral in character, and prioritizing the principle of conservatism.

Neutrality. The dimensions for earnings quality neutrality are unbiased income information. Where the principle of neutrality is the principle that informs the existence of the condition of the company's financial performance and does not cause adverse managerial conflicts. The relationship of earnings and neutrality is described as a management action that expresses the company's financial condition in a neutral manner, where the profit value will automatically avoid bias. Many studies have correlated the relationship between neutrality and earnings management. According to Scott (2009) earnings management is an option for management to make decisions regarding accounting policies to achieve certain goals. The trigger factors for earnings management actions are CEO changes, political impulses, incentives for managers in the form of bonuses, communication links between investors, and so on. Where earnings management can occur due to a game of profit determination that is both biased and loss. Where from this explanation it can be concluded that maintained management neutrality will have a tendency to minimize earnings management actions.

Protection for Investors. When an investor funds a company, investors will get some rights and authority protected by law through the enforcement of laws and regulations. These rights include the right to sue for the law when detecting alleged expropriation by management, the right to call extraordinary meeting of shareholders, voting in the election of the board, the right to get a fair proportion in dividend distribution, buying new securities, and participating in meetings shareholders, (La Porta et al., 2002). When a company violates or does not fulfill these rights, investors can demand company in court to obtain their rights (Shleifer \& Vishny, 1997).

The quality of financial information reported by companies is strongly influenced by the institutional structure of a country. The institutional structure has a relationship with the judicial system and legality as well as laws that bind companies in the capital market as well as law enforcers who have a purpose in providing protection for investors by creating an environment that can control the behavior and interests of regulators, investors, company executives and other participants.

Furthermore in the study of La Porta et al. (2002) added a mechanism for implementing protection for investors through securities law. Fundamental factors of capital market law that can be used as a protection mechanism for investors are standard litigation (litigation standards), disclosure requirements (disclosure requirements) and law enforcement by public (enforcement). Standard litigation in the capital market regarding the level of procedural difficulties in compensating for losses arising from errors in the company's financial statements and prospectus. While the disclosure requirements regarding the full disclosure in the company's prospectus. Meanwhile, law enforcement by the public reflects the strength of central bank, capital market, or other supervisory institutions in carrying out and implementing regulations in the capital market. The measure includes the characteristics of the capital market supervisory institution, the strength of conducting investigations, the 
power in making regulations, granting criminal sanctions if financial statements do not present material information, and the power to provide sanctions in the form of dismissal of the company's stock trading.

Bushman and Piotroski (2006) examine how institutional structures related to protection for investors form accounting numbers in financial statements. In this study only focused on conservatism as one of the variables measuring the quality of earnings. The underlying idea in this study is that the institutional structure of a country such as the judicial / legal system, political economy, tax regime, capital market law will provide incentives that affect the behavior of investors, regulators, corporate executives, and other participants.

From the explanation of the research above, it can be concluded that companies will tend to be more conservative when in a country that has a better quality of judicial system. In addition, companies in the capital market have a very high level of conservatism with the existence of strong law enforcement by the public. Regarding the political economy conditions, the researchers concluded that countries that have a high risk of expropriation by the government and countries that have dominance in ownership of the company will be less conservative. So in general Bushman and Piotroski (2006) have proven that company managerial decisions related to the principle of conservatism are influenced by the institutional structure of a country.

Corporate Governance. Corporate governance is a concept that does not have a single meaning. In 1992 corporate governance was first introduced by the Cadbury Committee which was used as a term. In the report referred to as the Cadbury report, this report is seen as a decisive turning point for the implementation of corporate governance throughout the world. Corporate governance means Cadbury Report as the principle that controls and directs the company to achieve a balance between the authority and strength of the company in giving authority to shareholders and stakeholders.

The Organization for Economic Cooperation and Development (2006) defines that corporate governance is a relationship structure and its relation to responsibility among related parties consisting of managers, commissioners, shareholders, and members of the board of directors, which are designed to support the achievement of a performance competitive needed to reach the company's main goals.

Based on the National Committee on Policy Governance (KNKG), "Good Corporate is one of the pillars of the market economy system. Corporate governance is closely related to trust in both the companies that implement it and the business climate in a country. The implementation of Good Corporate Governance supports the creation of a conducive business climate and fair competition.

The definition of corporate governance is different but has the same purpose and purpose. The conclusion that can be drawn from the explanation above is a system and a set of rules that regulate, manage and supervise the relationship between company managers and those related to a company in achieving company goals.

Leverage. One important factor in the element of funding is debt (leverage). Solvency (leverage) is described to see the extent to which a company's assets are financed by debt compared to its own capital (Weston \& Copeland, 1992). Whereas Kusumawati and Sudento (2005) describe leverage as the ability of a company to pay its debt by using its equity. Leverage can be understood as an estimator of the risks inherent in a company. That is, the greater leverage shows the greater investment risk. Companies with low leverage ratios haverisk of leverage a smaller.

Aratio leverage highexplains that a company has a higher debt compared to the total value of the company's assets (Horne, 1997). Where leverage is a ratio that compares the total debt of the company to the total value of the total assets of the company, then when investors analyze a company with a large number of assets and have a large risk of leverage, investors will move their investments to other companies, because large leverage will increase investment risk when the company is unable to repay the debt on time.

Debt may also have an ambiguous effect on earnings management. Some empirical research documents monitored by creditors enable better governance and thus contribute to reducing manager flexibility in terms of revenue management (Lee $\& \mathrm{Ng}, 2006$ ). In addition, 
Jiang et al. (2008); Maria and Alves (2011) prove the existence of a negative relationship between leverage and earnings management. However, the debt hypothesis predicts that highly leveraged firms tend to be involved in increasing earnings management earnings to avoidviolations covenant ((Watts \& Zimmerman, 1986); (DeFond and Jiambalvo, 1994)).

Company Size Company. Size is a large small-scale classification of companies based on sales size, total equity, and total assets (Brigham \& Houston, 2001). Classification of company size based on the value of total assets, the greater the value of total assets, the greater the size of the company. Large companies will be easy to make profits and relatively more stable than companies that have small asset values. Large companies tend to get more attention and control from the public or the government so that the company in presenting financial statements is more careful and will present a more transparent report so that management will avoid earnings management actions (Suryani, 2013). So from that it can be concluded that the greater the size of the company will have higher earnings quality information because it does not need to take profit manipulation or vice versa.

The relationship between company size and earnings management is still ambiguous. On the one hand, company size is often used as a proxy for political costs where the political cost hypothesis argues that large companies have greater incentives to avoid earnings management, because of the possibility of increased government control when the company is bigger and more profitable (Watts \& Zimmerman, 1986). On the other hand, company size is often used as an indicator of the importance of the company's internal control system (DeFond and Jiambalvo, 1994). Indeed, some previous studies have found a positive relationship between firm size and reliability of financial statements (McMullen, 1996); (Bédard et al., 2004). In addition, Meek et al. (2007) argue that management earnings may be lower in large companies. In fact, compared to other companies, large companies have lower information asymmetry, stronger governance structures and stronger external controls. In this study, estimating that the level of earnings management is related to the size of the company. According to previous studies ((Street \& Gray, 2002); (Othman \& Zeghal, 2006); (Cheng et al., 2010); (Zeghal \& Ahmed, 1990)), where using natural logarithms of total assets as a proxy for firm size (SIZE).

\section{RESEARCH HYPOTHESIS}

Effect of Implementation of Corporate Governance on Quality of Profit Moderated by Protection for Investors. In agency theory, conflicts that occur according to Jensen and Meckling (1976) in the long term each investor (principal) and manager (agent) want to maximize their respective utilities so that it will affect the company's financial reporting policies where when the profits of large companies then managers will get a big bonus, in addition to the differences in access to information managers easily expropriate companies, then as a basis for a mechanism that protects minority investors where as outsiders, the implementation of corporate governance can prevent the act of exploration carried out by management or insiders. According to Ahmed and Duellman (2007), and Ball et al. (2000) explain that implementation corporate governance can improve the quality of earnings information. This finding informs that law enforcement from the outside, the legal system, and the application of corporate governance to the company has an impact on improving the quality of reported earnings.

Quality of earnings is a level of corporate earnings information that can describe the economic impact of a real transaction. Unbiased income information is a dimension of neutrality. Where neutral earnings information is profit information that shows actual conditions without any manipulation and does not result in managerial conflicts that harm the company. The description of the correlation between earnings and neutrality is management behavior that expresses the financial condition corporate in a neutral manner, where automatically the value of earnings will be free from bias. Based on research by Scott (2009) arguing about earnings management which is a decision taken by management to achieve certain goals related to accounting policy decision making. So that it has a reflection of the concept in reporting earnings in financial disclosures. Therefore it can be concluded in this 
study that profit is said to have earnings quality when the earnings information is neutral in its nature.

The institutional structure owned by a country influences the quality of financial information disclosed by the company. The institutional structure has a connection with the judicial system and legality as well as the law both capital market law and law that binds companies and law enforcers with the aim of providing protection for investors by creating a legal environment that controls the interests and behavior of regulators, investors, corporate executives, and participants others. Previous studies have contributed to the findings of empirical evidence that concluded that protection for investors has a significant influence on earnings quality where previous researchers have not considered investor protection as a variable of moderation in the influence of the application of corporate governance in improving the quality of corporate profits.

The application of corporate governance to companies provides increased transparency in disclosure of information that will have an impact on improving the quality of corporate financial statements where this is also influenced by the better legal environment of a country. Therefore, it can be concluded that the effect of protection for investors strengthens the application of corporate governance to improve the quality of earnings. In addition, the findings of Klapper and Love (2002) prove that the state legal environment is related to protection for investors who will influence corporate governance in the company so that the report disclosed becomes more prime.

Previous research has not applied either directly or indirectly using the role of investor protection as a moderating variable in testing other variables that have an influence on earnings quality.

The results of previous studies found the effect of investor protection on earnings quality as well as the influence of implementation corporate governance on earnings quality where the findings were significant positional influences but still in the stage of regression testing where between variables are interconnected and such research has never been conducted in countries. ASEAN countries, therefore motivating researchers to carry out different tests of protection for investors as a moderating variable. So that researchers are deeper to examine the correlation between the application of corporate governance to the quality of earnings information that is moderated by investor protection in ASEAN countries.

$\mathrm{H} 1$ : The effect of corporate governance on the quality of earnings is increasingly high for countries with strong investor protection.

\section{METHODS OF RESEARCH}

In this study the design used was causal research. Based on Cooper and Emory (2015) explained that causal research is a study that examines the influence of the following variables: (1) Protection for investors on earnings quality; (2) Implementation of corporate governance on the quality of earnings for high investor protection countries. In this research,can also be said explanatory research. Where according to Kusumaningrum (2014) explains that explanatory research is research that seeks to explain the influence of variables through hypothesis testing.

Testing the effect of protection for investors and the application of corporate governance to earnings quality were tested using multiple regression models and moderation regression models. In this study using a measure based on its nature, namely neutrality as a measure of the quality of profits. In previous studies, many correlated earning management with profit neutrality, where the model of estimation of discretionary accruals is often used as a measure of earnings management. In this study themodel Modified Jones that will be used in predicting discretionary accrual values (Jensen \& Meckling, 1976). This Modified Jones model is the best model in detecting earnings management. The first step to get nondiscretionary accruals and discretionary accruals is to look for current accruals (CA).

CAit $=\Delta$ (current asset - cash $)-\Delta$ (current liabilities - current maturity of long term debt) 
Next is to calculate the value current accruals as follows:

$$
\text { CAit } / \text { TAit- } 1=\mathrm{a}_{0}(1 / \text { TAit- } 1)+\mathrm{a}_{1}(\text { ALSALit } / \text { TAit- } 1)+\varepsilon i t
$$

To calculate nondiscretionary accruals (NDACC) used the regression coefficient above (a0, a1) with the following formula:

$$
\text { NDACCit }=a_{1}\left(1 / \mathrm{TA}_{\mathrm{t}-1}\right)+\mathrm{a}_{2}\left(\Delta \mathrm{REV}_{\mathrm{t}}-\Delta \mathrm{REC}_{\mathrm{t}}\right)+\mathrm{a}_{3}\left(\mathrm{PPE}_{\mathrm{t}}\right)
$$

Discretionary accruals (DACC) obtained from the formula:

$$
\text { DACCit }=\text { CAit } / \text { TAit-1 }- \text { NDACCit }
$$

Where: CAit $=$ Current accruals company $\mathrm{i}$ in period $\mathrm{t} ; \triangle \mathrm{SALit}=$ Change in net sales of company $i$ in period $t$; NDACCit $=$ Non discretionary accruals company $i$ in period $t ; \Delta A$ / Rit $=$ Change in net receivables of company $i$ in period $t$; TAit- $1=$ Total assets of company $i$ in period $\mathrm{t}-1$; DACCit $=$ Discretionary accruals of company $\mathrm{i}$ in period $\mathrm{t}$.

Investor protection is a set of legal systems related to the protection of investments in capital markets made by the government to protect the act of expropriation or opportunity carried out by company managers. Sources of investor protection value data use the strength of investor protection index from (World Bank, 2011-2015). The index describes eight characteristics of protection for investors include: Extent of disclosure index, extent of shareholder rights index, ease of shareholder suits index, extent of ownership and control index, extent of transparency index, extent of director liability, extent of conflict of interest regulation index, and extent of shareholder governance index. These indices have arange measurementof 0 to 10 . The higher the index score indicates the stronger the protection of investors. In this study usingvariables dummy (number 1 for strong investor protection countries and number 0 for countries with low protection). The state is said to have strong investor protection if the average value of the strength protection investor index is 8.0-10.0 and the country is said to have low investor protection if the average protection index of the strength of investor index is 0-7.9.

Corporate governance is a system and a set of rules that regulate, manage and supervise relations between shareholders, administrators, creditors, governments, employees and external and internal stakeholders of the company that are interrelated in a company in achieving company goals. Data on Corporate Governance refers to data sources referring to data sources from the 2011-2015 ACGA (Asian Corporate Governance Association) survey that support the methodology used in the CSLA survey, which reflects the implementation of corporate governance in ASEAN countries, where reports include scores from each value index of corporate governance.

The relationship between company size and earnings management still has many dimensions. On the one hand, firm size is often used as a proxy for the political cost hypothesis where the political cost hypothesis argues that large companies have the pressure to avoid earnings management, because of the possibility of increased government control when the company is bigger and more profitable (Cheng et al., 2010). In this study using the natural logarithm of total assets as a proxy for company size (SIZE).

Maria and Alves (2011) found a negative relationship between leverage and earnings management. However, the debt hypothesis predicts that companies that have high leverage levels tend to be involved in increasing earnings management to avoid violations of covenants. Therefore, in this study the authors estimate that Management's income level is related to leverage company.

Leverage can be calculated using a ratio $=$ Total Debt $/$ Total Asset.

This study is subject to all companies in ASEAN countries which obtained data and sources that can be used in this study as follows:

1. Financial report data from companies listed on the stock exchange;

2. Investor protection data sources from the World Bank's 2011-2015 reference; 
3. Data Corporate governance sourced from the reports of each company in 2011-2015;

4. Data on financial reports sourced from the ASEAN State Stock Exchange website and the web of each company.

In this study the population used is a company that is included in the ACGA survey list for 2011-2015 outside of financial industry companies in ASEAN countries. The population in this study was 50 companies in each of the ten companies. While the number of samples is 250. The company selection sample used in this study is using the purposive sampling method with the following criteria:

1. Registered on stock exchanges in countries in ASEAN, namely: Indonesia, Malaysia, Philippines, Singapore, and Thailand;

2. Included in companies that were surveyed consecutively during 2011-2015 by ACGA;

3. Not including the financial industry (banks, leasing, and insurance). This is because financial companies have a financial structure that is different from other industries, therefore the size of earnings quality cannot be equated with other industries;

4. There is complete data for the period 2011 to 2015.

Data analysis techniques used to answer problems and research are moderating regression analysis. Moderation regression analysis is an analysis that involves moderating variables in building a model relationship.

The model of this analysis is used to test the strength of the moderating variable is investor protection on the effect of Corporate Governance on Quality of Profit, the regression equation is:

$$
Y_{1}=a_{1}+b_{1} X_{1}+b_{2} Z+b_{3} X_{1} Z+b_{4} X_{2}+b_{5} X_{3}+e_{1}
$$

Where: $Y=$ Quality Profit; $a=$ Value of regression constant in variable $X ; b_{1}=$ Coefficient Investor Protection; $b_{2}=$ Coefficient of Corporate Governance; $X=$ Investor Protection; $\mathrm{Z}=$ Corporate Governance; $\mathrm{e}=$ Error rate.

\section{RESULTS AND DISCUSSION}

Based on the results of the moderation analysis in Table 2, it shows that investor protection can moderate the effect of corporate governance on earnings quality, the interaction of investor protection with corporate governance influences the quality of earnings with a regression coefficient of 0.022 and a significance value of 0.012 . This significance value of 0.012 indicates that $\mathrm{H}_{1}$ accepted so that in this study the interaction of investor protection with corporate governance has an effect on the quality of earnings.

Table 2 - Moderate Regression Analysis

\begin{tabular}{llll}
\hline Variable & Coefficient regression & $\mathrm{t}$ count & Sig. \\
\hline Constant & -0.356 & 1.481 & 0,140 \\
Corporate Governance (CG) & 0,007 & 2.823 & 0,005 \\
Protection Investor (PI) & 2.182 & -2.526 & 0,012 \\
PI_CG & -0.022 & 0.441 & 0,660 \\
Leverage (LEV) & 0.050 & -2.734 & 0,007 \\
Corporate size (SIZE) & -0.034 & & \\
F count & 6.609 & & \\
Significant & 0,000 & & \\
R Square & 0,119 & & \\
Adjusted R Square & 0,101 & & \\
Variable dependent & Earning Management (DA)
\end{tabular}

Source: SPSS Processed.

This proves the influence of the application of corporate governance on improving the quality of earnings is higher in countries that provide high protection than countries that provide low investor protection. Protection interactions of investors with corporate governance can improve supervision and monitoring of financial reporting policies carried out 
by management so that the better the implementation of corporate governance implemented by companies, the minority investors are easy to supervise management of financial reporting policies and decision making so that management will be careful in reporting financial conditions and will avoid earnings management actions (Houqe, et al 2014).

In this study supports the research conducted by Ahmed and Duellman (2007) which states that corporate governance will improve the quality of earnings. These results indicate that in addition to the legal system and outside law enforcement (investor protection), the implementation of corporate governance in companies also provides incentives to management in the financial reporting process, which affects the quality of earnings presented. So that the quality of earnings published has excellent and informative quality.

Effect of control variables on earnings quality

Based on the results of the analysis show that leverage does not significantly influence the quality of earnings. Companies with degree of leverage a high are more difficult to carry out earnings management actions because companies with high levels of leverage will result in a high level of suspicion in making earnings management from various parties involved so that they will report the financial conditions according to current company conditions. Therefore companies with adegree of leverage highto continue to get the trust of the parties concerned can be reported financially according to the circumstances of the company so that they still get hope when they want to get additional capital, because when they conduct profit management it will be fatal to the company's growth come (Lee and $\mathrm{Ng} 2006$ ).

Furthermore, the variable size of the company, the results of the study in the moderation regression model indicate that the size of the company has a significant negative effect on earnings quality. This shows that the larger the company, the smaller the company conducts earnings management. This result is in accordance with the research of Mnif and Slimi (2016) which states that larger companies and their excellent performance tend to be careful in reporting their financial conditions and avoid earnings management, so that financial information is more transparent. This is also because large companies will be more concerned about investors as well as increased control from the public and the government.

\section{CONCLUSION}

Investor protection interactions with corporate governance affect the quality of earnings. Protection interaction of investors with corporate governance can improve supervision and monitoring of financial reporting policies carried out by management so that the better the implementation of corporate governance implemented by companies, the minority investors are easier to supervise management of financial reporting policies and decision making so that management will be cautious. Company size control variables negatively affect the quality of earnings by earnings management, while the leverage variable does not affect the quality of earnings.

\section{REFERENCES}

1. Ahmed, A. S., \& Duellman, S. (2007). Accounting conservatism and board of director characteristics: An empirical analysis. 43(2-3), 411-437.

2. Annisa, N. A., \& Kurniasih, L. (2012). Pengaruh corporate governance terhadap Tax avoidance. Jurnal Akuntansi \& Auditing, 8(2), 95-189.

3. Ardyansah, D. (2014). Pengaruh Size, Leverage, Profitability, Capital Intensity Ratio and Komisaris Independen terhadap Effective Tax Rate (ETR). 3(2), 371-379.

4. Ashbaugh, H., LaFond, R., \& Mayhew, B. W. (2003). Do nonaudit services compromise auditor independence? Further evidence. The accounting review, 78(3), 611-639.

5. Ball, R., Kothari, S., \& Robin, A. (2000). The effect of international institutional factors on properties of accounting earnings. Journal of accounting economics, 29(1), 1-51.

6. Basalamah, A. S., \& Jermias, J. (2005). Social and environmental reporting and auditing in Indonesia: maintaining organizational legitimacy? Gadjah Mada International Journal of Business, 7(1), 109-127. 
7. Beaver, W. (1989). Financial Reporting: An Accounting Revolution Prentice Hall Inc Upper Saddle River. Accounting review.

8. Bushman, R. M., \& Piotroski, J. D. (2006). Financial reporting incentives for conservative accounting: The influence of legal and political institutions. Journal of accounting economics, 42(1-2), 107-148.

9. Chambers, A. E., \& Penman, S. H. (1984). Timeliness of reporting and the stock price reaction to earnings announcements. Journal of accounting research, 21-47.

10. Cheng, M.-Y., Lin, J.-Y., Hsiao, T.-Y., \& Lin, T. W. (2010). Invested resource, competitive intellectual capital, and corporate performance. Journal of intellectual capital, 11(4), 433450.

11. Cooper, D. R., \& Emory, C. W. (2015). Business Research Methods, Chicago: Richard D. Irwin.

12. Dechow, P. (1994). Accounting earnings and cash flows as measures of firm performance: The role of accounting accruals. Journal of accounting economics, 18(1), 342.

13. DeFond, M. L., \& Hung, M. (2007). Investor protection and analysts' cash flow forecasts around the world. Review of Accounting Studies, 12(2-3), 377-419.

14. Fadhilah, R. (2014). Pengaruh Good Corporate Governance terhadap Tax Avoidance (Studi Empiris Pada Perusahaan Manufaktur yang Terdaftar di BEI 2009-2011). Jurnal Akuntansi, 2(1).

15. Francis, J. R., \& Wang, D. (2008). The joint effect of investor protection and Big 4 audits on earnings quality around the world. 25(1), 157-191.

16. Ghozali, I. (2013). Aplikasi Analisis Multivariate dengan Program IBM SPSS 21 Edisi 7. Semarang: Badan Penerbit Universitas Diponegoro.

17. Hung, M. (2000). Accounting standards and value relevance of financial statements: An international analysis. Journal of accounting economics, 30(3), 401-420.

18. Jensen, M. C., \& Meckling, W. H. (1976). Theory of the firm: Managerial behavior, agency costs and ownership structure. Journal of financial economics, 3(4), 305-360.

19. Klapper, L. F., \& Love, I. (2002). Corporate governance, investor protection, and performance in emerging markets. Journal of corporate Finance, 33(3), 703-728.

20. Klein, A. (2002). Audit committee, board of director characteristics, and earnings management. Journal of accounting economics, 33(3), 375-400.

21. La Porta, R., Lopez-de-Silanes, F., Shleifer, A., \& Vishny, R. (2002). Investor protection and corporate valuation. The journal of finance, 57(3), 1147-1170.

22. Leuz, C., Nanda, D., \& Wysocki, P. D. (2003). Earnings management and investor protection: an international comparison. Journal of financial economics, 69(3), 505-527.

23. Maharani, G., \& Suardana, K. (2014). Pengaruh Corporate Governance, Profitabilitas, and Karakteristik Eksekutif pada Tax avoidance Perusahaan Manufaktur. E-Jurnal Akuntansi, 525-539.

24. Niu, F. F. (2006). Corporate governance and the quality of accounting earnings: a Canadian perspective. International Journal of Managerial Finance, 2(4), 302-327.

25. Raharja, R. S. P. (2014). Analisis Pengaruh Corporate Governance terhadap Nilai Perusahaan. Diponegoro Journal Of Accounting, Vol. 3(No. 3), Hal.1-13.

26. Scott, W. R. (2009). Financial accounting theory. NJ: Prentice hall Upper Saddle River.

27. Shleifer, A., \& Vishny, R. W. (1997). A survey of corporate governance. The journal of finance, 52(2), 737-783.

28. Siagian, \& Tresnaningsih, E. (2011). Manajemen laba pada perusahaan dengan permasalahan free cash flow and peran moderasi dari monitoring eksternal. Jurnal Akuntansi and Keuangan Indonesia, 5(1), 30-49.

29. Street, D. L., \& Gray, S. J. (2002). Factors influencing the extent of corporate compliance with International Accounting Standards: summary of a research monograph. Journal of International Accounting, Auditing Taxation, 11(1), 51-76.

30. Velury, U., \& Jenkins, D. S. (2006). Institutional ownership and the quality of earnings. Journal of Business Research, 59(9), 1043-1051. Wardhani, R. (2009). Corporate 
Governance Mechanism, audit quality, and accrual quality: Indonesia manufacturing company evidence. International Journal of Business and Management (3), 168-179.

31. Watts, R. L., \& Zimmerman, J. L. (1986). Positive Accounting Theory. Contemporary Topics in Accounting Series. Edgewood Cliffs: NJ: Prentice-Hall.

32. Weston, J. F., \& Copeland, T. E. (1992). Manajemen Keuangan Jilid II (Y. Lamarto, Trans.). Jakarta: Erlangga.

33. Xie, B., Davidson III, W. N., \& DaDalt, P. (2003). Earnings management and corporate governance: the role of the board and the audit committee. 9(3), 295-316.

34. Zeghal, D., \& Ahmed, S. A. (1990). Comparison of social responsibility information disclosure media used by Canadian firms. 3(1). 